\title{
SYMPOSIUM ON THE IMMUNITY OF STATE OFFICIALS AN “INTERNATIONAL CRIME” EXCEPTION TO THE IMMUNITY OF STATE OFFICIALS FROM FOREIGN CRIMINAL JURISDICTION: NOT CURRENTLY, NOT LIKELY
}

\author{
Roger O'Keefe*
}

The happiest outcomes of the work of the International Law Commission (ILC) result when those charged with reporting on a topic elucidate the existing law with maximum objectivity and accuracy and when, where desired, they formulate such possibilities for its avowed progressive development as find a solid basis in emerging practice or international jurisprudence and are unlikely to arouse implacable opposition among members of the Commission or member states of the General Assembly. This history should be foremost in the minds of those presently leading the Commission's work on the immunity of state officials from foreign criminal jurisdiction as they come next session to report on possible limitations on and exceptions to such immunity. Whether the eventual aim is codification or reform, any consideration of this most controverted and combustible of contemporary questions of international law that is not based on an impartial and convincing assessment of relevant state practice and international case-law and that misreads the political temper of the times will end in tears, in the Commission itself and even more so in the Sixth Committee of the General Assembly.

What follows seeks to avert wailing and gnashing of teeth by providing a prophylactic dose of reality. ${ }^{1}$ Focusing on alleged exceptions to the immunity of state officials from foreign criminal jurisdiction when the charges specify international crimes, it sets out some home truths of which serious account must be taken if the ILC's work on the immunity of state officials from foreign criminal jurisdiction is to bear fruit.

\section{Positive Law}

It is hard to see how a dispassionate, rigorous observer could genuinely believe that there currently exists under customary international law any form of "international crime" exception to the immunity, ratione personae or ratione materiae, from foreign criminal jurisdiction from which a state is entitled to see its serving and former officials benefit.

As regards immunity ratione personae, the absence of any "international crime" exception is plain. The ICJ's categorical ruling in Arrest Warrant of 11 April 2000 that no exception existed in respect of allegations of grave breaches of the Geneva Conventions and crimes against humanity to the immunity ratione personae from which

* Professor of Public International Law at University College London.

Originally published online 14 December 2015.

${ }^{1}$ For a fuller treatment of most of the points made infra, with a detailed account of the relevant international and national jurisprudence and practice, including positions taken in the Sixth Committee, see ROGER O'KEEFE, INTERNATIONAL CRIMINAL LAW 373 , para. 9.29 note $47,422-5$, paras 10.41-10.44, 438-53, paras 10.71-10.91 and 458-9, paras 10.101-10.104 (2015). 
a serving minister for foreign affairs was said to benefit ${ }^{2}$ —and, by parity of reasoning, that no exception existed in respect of any alleged international crime to any species of immunity ratione personae- has been welcomed by the overwhelming majority of governments, applied by a host of national courts, accepted by the bulk of the ILC when discussing the first special rapporteur's conclusion to the same effect, ${ }^{3}$ queried by less than a handful of delegations to the Sixth Committee in the same context, and considered "not disputed" by a PreTrial Chamber of the International Criminal Court. ${ }^{4}$

When it comes to immunity ratione materiae, the situation is less settled but, in the final analysis, little different. ${ }^{5}$ Only on the most skewed approach to the identification of rules of customary international law could one currently discern any form of "international crime" exception to the immunity ratione materiae from foreign criminal jurisdiction from which a state is entitled to see its officials and ex-officials benefit. ${ }^{6}$ Indeed, there is nothing even approaching the widespread and representative concordance of state practice and concomitant opinio juris necessary for a rule of customary international law. Nor, for that matter, does practice or international jurisprudence exhibit any trend in favour of an "international crime" exception to immunity ratione materiae. If anything, a smattering of swallows has provoked a backlash against summer. The sparse, ambivalent body of national judicial and since-abrogated legislative practice against the availability of immunity ratione materiae in this context is counterbalanced by a sparse body of national judicial and prosecutorial practice and several pointed dicta from the $\mathrm{ICJ}^{7}$ in favour of immunity. Moreover, those very few jurisdictions that have declined to afford immunity in the few cases to have proceeded so far to judicial determination have all been western European. Conversely, African states jointly and severally, Chile, China, Israel, Mongolia and the United States-many of them states with a strong claim to being considered "specially affected" by any purported customary "international crime" exception-have all vociferously insisted on the grant of immunity ratione materiae to their serving and former officials in the face of foreign investigations or proceedings pertaining to alleged international crimes. (As it is, even in the relevant western European jurisdictions, the positions staked out by the courts or by individual investigating magistrates are not necessarily shared by the executive or legislative branches.) As for the little discussion to date in the Sixth Committee, only Belgium, Italy, Peru and Singapore are on record as suggesting de lege lata that there exists no obligation to afford immunity ratione materiae in criminal proceedings alleging international crimes, while China, France and Russia are on record to the contrary.

Legal Principle

The legal reasoning underpinning varieties of supposed "international crime" exception to the immunity of state officials from foreign criminal jurisdiction has fared poorly before the ICJ. Most damagingly, in Jurisdictional Immunities of the State the ICJ drew attention to what it saw as the fundamental flaw in any argument against

2 Arrest Warrant of 11 April 2000 (Dem Rep. Congo v. Belg.), Judgment, 2002 ICJ ReP. 3, 24-25, paras 58-59 (Feb. 14).

3 See Int'l Law Comm'n, Second report on immunity of State officials from foreign criminal jurisdiction, U.N. Doc. A/CN.4/631, at para. 55 (2010) [hereinafter "Second report"].

${ }^{4}$ Prosecutor v. Al Bashir, ICC-02/05-01/09-195, Pre-Trial Chamber, Decision on the Cooperation of the Democratic Republic of the Congo Regarding Omar Al-Bashir's Arrest and Surrender to the Court, para. 25 (Apr. 9, 2014), para. 25.

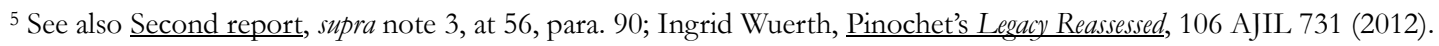

${ }^{6}$ The absence, as things stand, of an "international crime" exception to immunity ratione materiae is made all the clearer by the fact that the burden of proof lies on those seeking to establish a positive exception to the forum state's otherwise-applicable customary international obligation to afford immunity, not on those affirming the obligation.

7 See Arrest Warrant of 11 April 2000 (Dem Rep. Congo v. Belg.), Judgment, 2002 ICJ ReP. 3, 25, paras 59 and 61 (Feb. 14); Jurisdictional Immunities of the State (Ger. v.. It.), Judgment, 2012 ICJ ReP. 99, 136, para. 82, 140, para 93 and 141, para. 95 (Feb. 3). All are considered in more detail infra. 
immunity founded on the alleged international unlawfulness of the respondent's conduct, namely that it is premised on the outcome of adjudication on the merits, whereas the barring of adjudication on the merits is the essence of immunity. Highlighting this "logical problem,"8 the Court elaborated:

Immunity from jurisdiction is . . necessarily preliminary in nature. Consequently a national court is required to determine whether or not a foreign State is entitled to immunity as a matter of international law before it can hear the merits of the case brought before it and before the facts have been established. If immunity were to be dependent upon the State actually having committed a serious violation of international human rights law or the law of armed conflict, then it would become necessary for the national court to hold an enquiry into the merits in order to determine whether it had jurisdiction. If, on the other hand, the mere allegation that the State had committed such wrongful acts were to be sufficient to deprive the State of its entitlement to immunity, immunity could, in effect, be negated simply by skilful construction of the claim. ${ }^{9}$

The Court's insight is equally applicable to foreign criminal proceedings against serving or former state officials in respect of alleged international crimes. In the same judgment, the ICJ systematically and unsparingly rebutted jus cogens-based arguments against the availability of immunity from foreign jurisdiction. ${ }^{10}$ In doing so, moreover, while posting the formal caveat that the case before it related only to civil proceedings against the state sued as such, the Court went out of its way to include the following account of Arrest Warrant in its reasoning:

In Arrest Warrant, albeit without express reference to the concept of jus cogens, that the fact that a Minister for Foreign Affairs was accused of criminal violations of rules which undoubtedly possess the character of jus cogens did not deprive the Democratic Republic of the Congo of the entitlement which it possessed as a matter of customary international law to demand immunity on his behalf. ${ }^{11}$

In Arrest Warrant itself, the ICJ equally dismissed arguments against immunity founded on the combined effect of the mandatory extraterritorial jurisdiction and the obligation aut dedere aut judicare together included in multilateral treaties in the field of international criminal law, ${ }^{12}$ stating that,

although various international conventions on the prevention and punishment of certain serious crimes impose on States obligations of prosecution or extradition [and] requir[e] them to extend their criminal

\footnotetext{
${ }^{8}$ Jurisdictional Immunities of the State (Ger. v. It.), Judgment, 2012 ICJ Rep. 99, 136, para. 82 (Feb. 3).

${ }^{9} \underline{I d}$.

${ }^{10} \underline{I d}$., at 140-1, paras 93-95. For jus cogens-based judicial reasoning denying the availability of immunity ratione materiae in criminal proceedings for alleged international crimes, see Cass. Pen., Lozano (Mario Luiz) v. Italy, 24 luglio, 2008, No. 31171/2008 (Ita.), ILDC 1085 (IT 2008), para. 6. Immunity was eventually upheld on other grounds. See also Tribunal fédéral [TF] [Federal Supreme Court], Jul. 25, 2012, Doss. No. BB.2011.140 (Swi.), paras 5.3.4-5.3.5, where the court speaks, more than a little optimistically, of "a manifest tendency on the international plane to want to restrict the immunity of (former) heads of state in cases of crimes pertaining to jus cogens" (author's translation). The ratio of the decision, however, as evident $\underline{i d}$., para. 5.4.3, appears ultimately premised on the court's reading of an official statement made by Swiss legislators when enacting into Swiss law the crimes within the jurisdiction of the ICC. It is also worth noting that the decision of the Swiss minister challenged before the court predates the ICJ's dicta in Jurisdictional Immunities, as do all the pleadings in the challenge bar the réplique (two days after the ICJ's judgment) and the duplique (two months later), neither of which could by that point have incorporated the ICJ's jurisprudence.

${ }^{11}$ Jurisdictional Immunities of the State (Ger. v. It.), Judgment, 2012 ICJ Rep. 99, 141, para. 95 (Feb. 3).

12 For the most famous but narrowest judicial argument to this effect, see $\mathrm{R} v$. Bow Street Metropolitan Stipendiary Magistrate, $e x$ parte Pinochet Ugarte (No. 3) [2000] 1 A.C. 147 (HL) 266-267 (Lord Saville) and 277-278 (Lord Millet) (Eng.), Mar. 24, 1999).
} 
jurisdiction, [this] in no way affects immunities under customary international law, including those of Ministers for Foreign Affairs. ${ }^{13}$

Such immunities, the Court stressed, "remain opposable before the courts of a foreign State, even where those courts exercise such a jurisdiction under these conventions." 14 In the same case, in which immunity ratione personae alone was at issue, the Court, having fashioned a pretext on which also to mention immunity ratione materiae, observed:

Provided that it has jurisdiction under international law, a court of one State may try a former Minister for Foreign Affairs of another State in respect of acts committed prior or subsequent to his or her period of office, as well as in respect of acts committed during that period of office in a private capacity. ${ }^{15}$

In this way the ICJ did not just implicitly reject the claim that immunity ratione materiae poses no bar under customary international law to the foreign prosecution of a serving or former state official for an alleged international crime. The Court's cunning reference to the unavailability of immunity ratione materiae in respect of acts performed "in a private capacity" — rather than to the availability of immunity in respect of acts performed in an official capacity, or to "official acts," both of which might have been read down to exclude acts under mere colour of officialdom-takes aim at the argument ${ }^{16}$ that, rather than implicating an exception, international crimes do not attract immunity ratione materiae in the first place. ${ }^{17}$

While these statements have all been by way of dicta and are only subsidiary means for the determination of the law at issue, ${ }^{18}$ it would be wilful blindness to fail to register their message.

\section{Political Will}

It would be a mistake to think that there exists among member states of the General Assembly the political will for the acceptance, even by explicit way of progressive development, of an "international crime" exception to the immunity of state officials, ratione personae or materiae, from foreign criminal jurisdiction. The reality manifest except to those who will not see is that, beyond a minority of states, there is little diplomatic appetite for

13 Arrest Warrant of 11 April 2000 (Dem Rep. Congo v. Belg.), Judgment, 2002 ICJ ReP. 3, 25, para. 59 (Feb. 14). See also Int'l Law Comm'n, Third report on immunity of State officials from foreign criminal jurisdiction, UN Doc. a/CN.4/646, at para. 55 (2011).

14 Arrest Warrant of 11 April 2000 (Dem Rep. Congo v. Belg.), Judgment, 2002 ICJ ReP. 3, 25, para. 59 (Feb. 14).

$15 \underline{I d}$., at 25 , para 61 .

${ }^{16}$ For judicial arguments to this effect, see $\mathrm{R} v$. Bow Street Metropolitan Stipendiary Magistrate, ex parte Pinochet Ugarte (No. 1) [2000] 1 A.C. 61 (HL) 109 and 111 (Lord Nicholls), 115-16 (Lord Steyn) and 118 (Lord Hoffmann) (Eng.), the case subsequently having been annulled, with the consequence that it cannot be counted for the purposes of state practice; Hof Amsterdam, Nov. 20, 2000 NJ 2001, 51 m. nt., (Wijngaarde et al. v. Bouterse) 3 Y.B. INT'L HumanitARIAN L., para. 4.2, Nov. 20, 2000), overturned on appeal on other grounds.

${ }^{17}$ For further indications that the fact that state officials act in excess of authority or instructions, contrary to instructions or contrary to the general law, including the criminal law, of the state of which they are officials does not of itself mean that their acts are not performed in an official capacity, see paras 2 and 3 of the commentary to draft art. 43 of the ILC's Draft Articles on Consular Relations, Report of the International Law Commission on the work of its thirteenth session, UN GAOR, 16th Sess., Supp. 10, at 92, UN Doc. A/4843, reprinted in [1961] 2 Y.B. Int'l L. Comm'n 92, UN Doc. A/CN.4/SER.A/1961/Add.1; R v. Bow Street Metropolitan Stipendiary Magistrate, ex parte Pinochet Ugarte (No. 3) [2000] 1 A.C. 147 (HL) 203 (Lord Browne-Wilkinson), 217-18 (Lord Goff), 242 (Lord Hope) and 271 (Lord Millet); Second report, supra note 3, at 15-19, paras 27 and 29-31. It ought to go without saying that it is immaterial for the purposes of immunity from foreign criminal jurisdiction whether the act was allegedly contrary to the criminal law of the forum state, as opposed to the state served by the official. Were this not so, there would be no point in discussing immunity from foreign criminal jurisdiction in the first place.

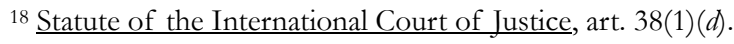


foreign prosecutions for alleged international crimes of state officials and ex-officials otherwise benefiting under customary international law from immunity.

Whatever the rights and wrongs, state practice-from the concerted fury of African states and the stern rebuke of China, Israel and the United States in relevant cases to the signal absence of any groundswell of opposition among delegates to the Sixth Committee to the first special rapporteur's rejection of an "international crime" exception to immunity, ratione personae or materiae - indicates that a substantial number of states, at the very least, simply do not want their officials or affairs adjudicated on in foreign criminal courts without their consent. This is so, for that matter, even in what tends to be the less embarrassing context of common crimes. Consider the current dispute between Italy and India over the latter's arrest and declared intention to prosecute two Italian marines for killing Indian nationals in the course of duty ${ }^{19}$ or the recent spat between India and the United States over the arrest and prosecution of an Indian consular official in New York City. ${ }^{20}$ Consider too the expansive provision for immunity, ratione personae and materiae, from foreign criminal jurisdiction in the raft of diplomatic, consular and cognate conventions, status of forces and status of mission agreements, and the like. When it comes specifically to international crimes, African states, for their part, as their Protocol on Amendments to the Protocol on the Statute of the African Court of Justice and Human Rights of 27 June 2014 shows, go so far as to oppose the nonconsensual prosecution of their high-ranking officials even before an international court created by them and their peers and to whose statute they are party.

That said, some states seem confident that their own serving and former officials will never be prosecuted for international crimes in foreign courts or seem content to waive any immunity that might serve to shield notorious figures from their own past regimes. But even a number of these states appear reluctant, for diplomatic or other reasons, to see their own courts used for private prosecutions of foreign officials and ex-officials without the consent of the accused's state.

\section{Conclusion and Future Directions}

The challenge for the ILC's scholarly, well-intentioned second special rapporteur on the immunity of state officials from foreign criminal jurisdiction is that a solid body of members of the Commission and of states in the Sixth Committee will view a refusal to face or an attempt to face down the realities highlighted here as special pleading and will give it the shortest of shrifts. The spectacle will not be edifying. What is "essential," therefore, in the words of members of the Commission at its most recent session, is "that there be transparency and an informed debate on whatever choices [are] to be made and on the direction to be taken." 21 It is to be hoped that the perhaps-unpalatable truths outlined here are taken as starting points from which the special rapporteur might seek to suggest more lateral-thinking ways of resolving circumstantial tensions between the moral imperatives of international criminal justice and the prudential desiderata of friendly relations among states.

What such lateral thinking might involve would be for the special rapporteur and the Commission to determine, taking into account comments by states. That said, one idea might be to propose by way of progressive development a draft article, applicable to immunity ratione personae and immunity ratione materiae alike, along the following lines:

19 See The "Enrica Lexie" Incident (It. v. India), Case No. 24, Request for the Prescription of Provisional Measures, Order of Aug. 25, 2015, (ITLOS, Aug. 24, 2015), and ongoing proceedings in the case.

${ }^{20}$ See Kristina Daugirdas \& Julian Davis Mortenson, Manhattan Arrest of Indian Consular Officials Sparks Public Dispute Between the United States and India, 108 AJIL 325. Although the furore centered as much on the alleged manner of the suspect's arrest, the subsequent criminal proceedings against her and the immunity from jurisdiction claimed for her by India equally factored.

${ }^{21}$ Int'l Law Comm'n, Rep. on the Work of its Sixty-Seventh session, UN Doc. A/70/10, 121, para. 194 (2015). 


\section{Draft article X}

1. A state against whose serving or former official foreign proceedings for an alleged international crime are barred by immunity is obliged genuinely to investigate the allegations and, where appropriate, genuinely to prosecute the person concerned or to surrender that person to a competent international criminal court for the purpose of prosecution.

2. The state in which proceedings were barred by immunity is obliged to afford the greatest measure of assistance in connection with the investigation and any resulting criminal proceedings in the official's state.

3. Any offer of such assistance may not be arbitrarily refused.

A further progressive development might be a more general draft article, applicable to both immunity ratione personae and immunity ratione materiae and to both international and municipal crimes, and drawing on a provision pertaining to the representatives of member states in the Convention on the Privileges and Immunities of the United Nations 1946, ${ }^{22}$ to the following effect:

\section{Draft article Y}

A state is under an obligation to give due consideration to waiving any immunity enjoyed by its serving or former officials in any case where in the opinion of that state the immunity would impede the course of justice and can be waived without prejudice to the purpose for which the immunity is accorded.

Whatever proposals are put forward, however, the special rapporteur and the Commission would be well advised to reckon seriously with the reality that the present and foreseeable positive law reflect more apology than utopia.

22 See Convention on the Privileges and Immunities of the United Nations, Feb. 13, 1946, 1 UNTS 15 (corrigendum 90 UNTS 327), section 14 . 